\title{
MODEL PEMBELAJARAN DISCOVERY LEARNING PADA MATERI LUAS DAN KELILING BANGUN DATAR KELAS IV SEKOLAH DASAR
}

\author{
Tutwuri Handayani \\ Guru SD Negeri 003 Bintan Utara \\ Email: tutuwurisdn003bintanutara@gmail.com
}

\begin{abstract}
Absctrac
The implementation of the 2013 curriculum $(K-13)$ has a consequence that teachers must be more qualified in carrying out learning activities. Because K-13 mandates the application of a scientific approach (5M) which includes observing, asking, gathering information, reasoning / associating, and communicating. Mathematic Teachers North Bintan Elementary School often did not give opportunity for students to get the opportunity to think creatively, critically, collaboratively and communicatively. This happens because the learning model carried out by the teacher has not implemented a learning model that can optimally accommodate students' interests and potential. Researchers have taught as classroom teachers since 2012. In the 2018/2019 academic year, researchers taught fourth grade. As a class teacher, the writer teaches all subjects, including PPKN, Indonesian, Mathematics, Science, Social Studies, and $S B d P$. Of the six subjects, the lowest average score for daily tests was mathematics. Basic mathematics competencies are in semester II include KD 3.9, namely; Explaining and determining the perimeter and area of squares, rectangles, and triangles as well as the square relationship with the square root is the KD with the lowest score for the daily test scores of grade IV a SD Negeri 003 Bintan Utara. Class IV mathematics learning process at SD Negeri 003 North Bintan often did not make students get the opportunity to think creatively, critically, collaboratively and communicatively, this happened because the learning model carried out by the teacher has not implemented a learning model that could optimally accommodate students' interests and potential. The impact was that many students could not achieve the minimum mastery level at 72. The purpose of writing this paper was to describe mathematics learning at SD Negeri 003 North Bintan, and to describe the Learning Implementation Plan with the Discovery Learning learning model, and to describe the Discovery Learning scenario. The basis for this paper was the low level of understanding of students in doing math problems.
\end{abstract}

Keywords : Discovery Learning, the wide materials and flat building.

\begin{abstract}
Abstrak
Diimplementasikannya kurikulum 2013 (K-13) membawa konsekuensi guru yang harus semakin berkualitas dalam melaksanaan kegiatan pembelajaran. Karena K-13 mengamanatkan penerapan pendekatan saintifik $(5 \mathrm{M})$ yang meliputi mengamati, menanya, mengumpulkan informasi, menalar/ mengasosiasikan, dan mengomunikasikan. Pembelajaran matematika kelas IV di SD Negeri 003 Bintan Utara sering membuat siswa tidak mendapatkan kesempatan berpikir kreatif, kritis, kolaboratif dan komunikatif, hal ini disebabkan oleh model pembelajaran yang dilakukan guru belum menerapkan model pembelajaran yang dapat mengakomodir secara maksimal minat dan potensi siswa. Peneliti telah mengajar sebagai guru kelas sejak tahun 2012. Pada tahun pelajaran 2018/2019 peneliti mengampu kelas empat. Sebagai guru kelas penulis mengajar semua pelajaran antara lain PPKN, Bahasa Indonesia, Matematika, IPA, IPS, dan SBdP. Dari enam mata pelajaran tersebut hasil nilai rata-rata ulangan harian paling rendah adalah matematika. Kompetensi dasar matematika pada semester II antara lain KD 3.9 yaitu; Menjelaskan dan menentukan keliling dan luas persegi, persegi panjang, dan segitiga serta hubungan pangkat dua dengan akar pangkat dua adalah KD yang paling rendah hasil nilai ulangan harian siswa kelas IV a SD Negeri 003 Bintan Utara. Pembelajaran matematika kelas IV di SD Negeri 003 Bintan Utara sering membuat siswa tidak mendapatkan kesempatan berpikir kreatif, kritis, kolaboratif dan komunikatif, hal ini disebabkan oleh model pembelajaran yang dilakukan guru belum menerapkan model pembelajaran yang dapat mengakomodir secara maksimal minat dan potensi siswa. Dampaknya banyak siswa yang tidak bisa mencapai ketuntasan minimal yang ditetapkan yaitu 72 . Tujuan penulisan makalah ini adalah untuk mendeskripsikan pembelajaran matematika di SD Negeri 003 Bintan Utara, mendeskripsikan
\end{abstract}


Rencana Pelaksanaan Pembelajaran dengan model pembelajaran Discovery Learning, mendeskripsikan skenario pembelajaran Discovery Learning. Yang mendasari makalah ini adalah masih rendahnya tingkat pemahaman siswa dalam mengerjakan soal matematika. Penulisan makalah ini bertujuan untuk mendeskripsikan kondisi nyata pembelajaran yang ada di kelas.

\section{Kata Kunci : Discovery Learning, Luas dan Keliling Bangun Datar.}

\section{PENDAHULUAN}

Kemajuan teknologi informasi dan komunikasi telah merubah gaya hidup manusia, baik dalam bekerja, bersosialisasi, bermain maupun belajar. Memasuki abad 21 kemajuan teknologi tersebut telah memasuki berbagai sendi kehidupan, tidak terkecuali dibidang pendidikan. Tuntutan belajar dengan menerapkan pola pikir kritis, kreatif, kolaboratif, dan komunikatif ini yang membuat sebagian siswa mengalami kesulitan untuk mengikuti perubahan paradigma belajar yang begitu cepat.

Pembelajaran matematika kelas IV di SD Negeri 003 Bintan Utara masih monoton baik metode maupun strategi yang diterapkan guru. Guru mengajar dengan metode ceramah dan penugasan. Hal ini berdampak pada rendahnya kreatifitas siswa dalam memunculkan kemampuannya dalam menggali dan menemukan sendiri pengetahuan yang diperlukan.

Berdasarkan uraian latar belakang di atas, penulis merasa bahwa siswa mengalami kejenuhan dalam belajar. Hal ini muncul karena guru kurang kreatif dalam melaksanakan pembelajaran di kelas. penulis mengaharapkan adanya perubahan cara belajar siswa yang menjadi lebih kritis, kreatif, inovatif dan kolaboratif dengan menemukan dan memecahkan masalah bersama teman-teman di kelasnya. Kegiatan pembelajaran didominasi oleh siswa sehingga siswa bukan lagi obyek melainkan pelaku dalam pembelajaran di kelasnya.

Pembelajaran matematika di sekolah dasar tidak bisa terlepas dari sifat-sifat perkembangan intelektual siswa yang kita ajar. Menurut (Suherman dkk, 2001: 65) kita perlu memperhatikan beberapa sifat atau karakteristik pembelajaran matematika berikut :

Pembelajaran matematika mengikuti metode spiral. 1). Dalam setiap memperkenalkan konsep atau bahan yang baru perlu memperhatikan konsep atau bahan yang telah dipelajari siswa sebelumnya. 2). Pembelajaran matematika menekankan pola pikir deduktif. Matematika adalah ilmu deduktif, matematika tersusun secara deduktif aksiomatik. Namun demikian kita harus dapat memilih pendekatan yang cocok dengan kondisi siswa yang kita ajar. Misal sesuai dengan perkembangan intelektual siswa, maka dalam pembelajaran matematika belum seluruhnya menggunakan pendekatan deduktif tapi masih campur ingin induktif. 3)Pembelajaran matematika menganut kebenaran konsistensi. Kebenaran dalam matematika sesuai dengan stuktur deduktif aksiomatik. Kebenarankebenaran dalam matematika pada dasarnya merupakan kebenaran konsistensi tidak ada pertentangan antara kebenaran suatu konsep dengan yang lainnya. Dari teori di atas dapat di simpulkan bahwa pembelajaran matematika adalah berjenjang (bertahap). Bahan kajian matematika diajarkan secara berjenjang atau bertahap yaitu dimulai dari hal yang konkret dilanjutkan ke hal yang abstrak, dari hal yang sederhana ke hal yang komplek.

Menghitung Luas bangun datar adalah luas daerah yang dibatasai oleh sisi-sisi bangun datar tersebut: 1) Luas Persegi Untuk mencari luas persegi yaitu dengan mengalikan sisi dengan sisi. $\mathrm{L}=$ sisi $\mathrm{x}$ sisi atau $\mathrm{L}=$ Sisi 2) Luas Persegi panjang, Luas persegi panjang yaitu panjang $x$ lebar. 3) Luas segitiga. Luas segitiga yaitu $1 / 2$ alas $\mathrm{x}$ tinggi.

Menghitung Keliling Bangun Datar. 1) Keliling persegi. Untuk menghitung keliling persegi yaitu : sisi+sisi+sisi+sisi atau 4 x sisi. 2) Keliling persegi panjang Untuk menghitung persegi panjang yaitu panjang + lebar + panjang + lebar atau $2 \times(\mathrm{p}+1) .3)$ Keliling segitiga Untuk menghitung segitiga yaitu sisi+sisi+sisi. Atau dengan rumus $3 \mathrm{x}$ sisi untuk segi tiga sama sisi.

Pengertian Model Pembelajaran. Dalam Bistari (2015: 293) dipaparkan beberapa pengertian tentang model pembelajaran menurut para ahli sebagai berikut: a) Ruseffendi mengungkapkan bahwa model pembelajaran adalah sebagai suatu desain yang menggambarkan proses rincian dan penciptaan situasi lingkungan yang memungkinkan siswa berinteraksi sehingga terjadi perubahan atau perkembangan pada siswa. b)Akhmad Sudrajad mengungkapkan model pembelajaran pada dasarnya merupakan bentuk pembelajaran yang tergambar dari awal sampai akhir yang disajikan secara khas oeh guru. Dengan kata lain, model pembelajaran merupakan bungkus atau bingkai dari penerapan suatu pendekatan, metode dan teknik pembelajaran; c) Soekamto mengungkapkan model adalah kerangka konseptual yang melukiskan prosedur yang sistematis dan mengorganisasikan pengalaman belajar untuk mencapai tujuan belajar tertentu dan berfungsi sebagai pedoman bagi 
perancang pembelajaran dan para pengajar dalam merencanakan aktivitas belajar mengajar; d) Winataputra mengungkapkan model pembelajaran adalah kerangka konsepual yang melukiskan prosedur yang sistematis dalam mengorganisaasikan pengalaman belajar untuk mencapai tujuan blajar tertentu dan berfungsi sebagai pedoman bagi para pencanang pembelajaran dan para pengajar dalam mencanangkan dan melaksanakan aktivitas pembelajaran; e) Joyce dan Marsha Weil's mengungkapkan model pembelajaran adalah suatu rancangan atau pola yang dapat digunakan untuk membentuk kurikulum (pembelajaraan dalam jangka waktu lama) untuk mendesain bahanbahan pembelajaran dan untuk mengarahkan guru mengaajar serta setting lainnya di dalam kelas; f) Agus Suprijono mengungkapkan pola yang digunakan sebagai pedoman dalam merencanakan pembelajaran di kelompok maupun tutorial.

Berdasarkan beberapa pendapat ahli di atas, dapat disimpulkan bahwa model pembelajaran merupakan prosedur yang sistematis dalam mengorganisaasikan pengalaman belajar untuk mencapai tujuan belajar tertentu dan berfungsi sebagai pedoman bagi para pencanang pembelajaran dan para pengajar dalam mencanangkan dan melaksanakan aktivitas pembelajaran.

Ciri-ciri Model Pembelajaran. a) Rasional teoritik yang logis yang disusun oleh para penciptaa atau pengembanganya; b) Landasan pemikiran tentang apa dan bagaimana siswa belajar. c)Tingkah laku mengajar yang diperlukan agar model tersebut dapat dilaksanakan dengan berhasil. d)Lingkungan belajar yang diperlukan agar tujuan pembelajaran dapat tercapai.

Memilih Model Pembelajaran yang Baik. Sebagai seorang guru harus mampu memilih model pembelajaran yang tepat bagi peserta didik. Karena itu dalam memilih model pembelajaran guru harus memperhatikan keadaan atau kondisi peserta didik, bahan pelajaran serta sumbersumber belajar yang ada agar penggunakan model pembelajaran dapat diterapkaan secara efektif daan menunjang keberhasilan belajar peserta didik.

Seorang guru diharapkan memiliki motivasi dan semangat pembaharuan dalam proses pembelajaraan yang dijalaninya. Guru yang kompeten adalah guru yang mampu mengelola program belajar mengajar. Mengelola di sini memiliki arti yang luas yang menyangkut bagaimana seorang guru mampu menguasai keterampilaan dasar mengajar, seperti membuka dan menutup pelajaran, menjelaskan, memvariasi media, bertanya, memberi penguatan, dan sebagainya, juga bagaimana guru menerapkan strategi, teori belajar dan pembelajaran, dan melaksanakan pembelajaran yang kondusif.

Pendapat serupa dikemukakan oleh colin Marsh dalam Bistari (2015), yang menyatakan bahwa guru harus memiliki kompetensi mengajar, memotivasi peserta didik, membuat model instruksional, mengelola kelas, berkomunikasi, merencanakan pembelajaran dan mengevaaluasi. Semua kompetensi tersebut mendukung keberhasilan guru dlam mengajar. Setiap guru harus memiliki kompetensi adaptif terhadap setiap perkembangan ilmu pengetahuan dan kemajuan di bidang pendidikan, baik yang menyangkut perbaikan kualitas pembelajaran maupun segala hal yang berkaitan dengan peningkatan prestasi belajar peserta didiknya.

Adapun macam-macam Model Pembelajaran dalam Bistari 2015: antaralain: (a) Model Pembelajaran Example Non Example; (b) Model Pembelajaran Picture and Picture; (c) Model Pembelajaran Numbered Head Together (NHT); (d)Model Pembelajaran Kooperatif Tipe Script; (e) Model Pembelajaran Kepala bernomor Struktur (Numbered Head Together= NHT); (f) Model Pembelajaran Student Teams-Achievement Divisions (STAD); (g)Pembelajaran Model Jigsaw; (h) Model Pembelajaran Berbasis Masalah (Problem Based Introduction); (i) Model Pembelajaran Mind Mapping; (j) Model Pembelajaran Make a Match; (k)Model Pembelajaran Think Pair Share (TPS); (1)Model Pembelajaran Debat Aktif; (m) Model Pembelajaran Artikulasi; (n)Model Pembelajaran Role Playing; (o).Model Pembelajaran Group Investigation.

Ada banyak model pembelajaran yang dapat diterapkan untuk mengatasi hal di atas. Salah satu diantaranya penulis memilih model pembelajaran Discovery Learning karena syntak dalam pembelajaran ini banyak kesesuaian dengan kebutuhan siswa yang ada di kelas IV yang penulis ampu saat ini.Berikut disajikan bebarapa rumusan masalah antara lain; Bagaimana kondisi pembelajaran matematika di SD Negeri 003 Bintan Utara? Bagaimana bentuk RPP yang menerapkan pembelajaran Discovery Learning ? Bagaimana skenario pembelajaran matematika materi luas dan keliling bangun datar dengan model pembelajaran Discovery Learning?

Tujuan penulisan artikel ini adalah untuk mendeskripsikan pembelajaran matematika di SD Negeri 003 Bintan Utara, mendeskripsikan Rencana Pelaksanaan Pembelajaran model Discovery Learning, mendeskripsikan skenario pembelajaran model Discovery Learning. Manfaat dari penulisan artikel ini adalah: Menumbuhkan pola pikir dalam belajar yang kreatif, kritis, kolaboratif dan komunikatif. Meningkatkan motivasi belajar siswa secara konsisten baik bagi 
siswa yang memiliki kemampuan yang tinggi, sedang dan rendah dan resistensi.Mempermudah siswa dalam mengerjakan soal pecahan yang menuntut berpikir tingkat tinggi.Dapat meningkatkan motivasi guru untuk menciptakan pembelajaran

Menurut Wilcox (Slavin, 1977), dalam pembelajaran dengan penemuan siswa didorong untuk belajar sebagian besar melalui keterlibatan aktif mereka sendiri dengan konsep-konsep dan prinsip-prinsip, dan guru mendorong siswa untuk memiliki pengalaman dan melakukan percobaan yang memungkinkan mereka menemukan prinsipprinsip untuk diri mereka sendiri.

Pengertian discovery learning menurut Jerome Bruner adalah metode belajar yang mendorong siswa untuk mengajukan pertanyaan dan menarik kesimpulan dari prinsipprinsip umum praktis contoh pengalaman. Dan yang menjadi dasar ide J. Bruner ialah pendapat dari piaget yang menyatakan bahwa anak harus berperan secara aktif didalam belajar di kelas. Untuk itu Bruner memakai cara dengan apa yang disebutnya discovery learning, yaitu dimana murid mengorganisasikan bahan yang dipelajari dengan suatu bentuk akhir.

Menurut Bell (1978) belajar penemuan adalah belajar yang terjadi sebagia hasil dari siswa memanipulasi, membuat struktur dan mentransformasikan informasi sedemikian sehingga ie menemukan informasi baru. Dalam belajar penemuan, siswa dapat membuat perkiraan (conjucture), merumuskan suatu hipotesis dan menemukan kebenaran dengan menggunakan prose induktif atau proses dedukatif, melakukan observasi dan membuat ekstrapolasi.

Tiga ciri utama belajar menemukan yaitu: (1) mengeksplorasi dan memecahkan masalah untuk menciptakan, menggabungkan dan menggeneralisasi pengetahuan; (2) berpusat pada siswa; (3) kegiatan untuk menggabungkan pengetahuan baru dan pengetahuan yang sudah ada. Blake et al. membahas tentang filsafat penemuan yang dipublikasikan oleh Whewell. Whewell mengajukan model penemuan dengan tiga tahap, yaitu: (1) mengklarifikasi; (2) menarik kesimpulan secara induksi; (3) pembuktian kebenaran (verifikasi), teori konstruktivisme memiliki ciri-ciri yaitu :Menekankan pada proses belajar, bukan proses mengajar, mendorong terjadinya kemandirian dan inisiatif belajar pada siswa, memandang siswa sebagai pencipta kemauan dan tujuan yang ingin dicapai, berpandangan bahwa belajar merupakan suatu proses, bukan menekan pada hasil, mendorong siswa untuk mampu melakukan penyelidikan, menghargai peranan pengalaman kritis dalam belajar, mendorong berkembangnya rasa ingin tahu secara alami pada siswa, penilaian belajar lebih menekankan pada kinerja dan pemahaman siswa, mendasarkan proses belajarnya pada prinsip-prinsip kognitif, banyak menggunakan terminilogi kognitif untuk menjelaskan proses pembelajaran; seperti predeksi, inferensi, kreasi dan analisis, menekankan pentingnya "bagaimana" siswa belajar, mendorong siswa untuk berpartisipasi aktif dalam dialog atau diskusi dengan siswa lain dan guru, sangat mendukung terjadinya belajar kooperatif, menekankan pentingnya konteks dalam belajar, memperhatikan keyakinan dan sikap siswa dalam belajar, memberikan kesempatan kepada siswa untuk membangun pengetahuan dan pemahaman baru yang didasari pada pengalaman nyata.

Berdasarkan ciri-ciri pembelajaran kontruktivisme tersebut diatas, maka dalam penerapannya didalam kelas sebagai berikut : a) Mendorong kemandirian dan inisiatif siswa dalam belajar, b) Guru mengajukan pertanyaan terbuka dan memberikan kesempatan beberapa waktu kepada siswa untuk merespon, c) Mendorong siswa berpikir tingkat tinggi, d) Siswa terlibat secara aktif dalam dialog atau diskusi dengan guru atau siswa lainnya,e)Siswa terlibat dalam pengetahuan yang mendorong dan menantang terjadinya diskusi, f) Guru menggunakan data mentah, sumber-sumber utama dan materi-materi interaktif, g) Dari teori belajar kognitif serta ciri dan penerapan teori kontruktivisme tersebut dapat melahirkan strategi discovery learning.

\section{HASIL DAN PEMBAHASAN PENELITIAN}

Kondisi Pembelajaran matematika di kelas IV SDN 003 Bintan Utara. SD Negeri 003 Bintan Utara berada di Jl. Taman Sari No. 14 Tanjung Uban Utara . Memiliki jumlah siswa 370 dengan jumlah rombel 14 rombel. Kelas IV paralel yaitu IV a dan IV b. Penulis mengampu kelas IVa dengan jumlah siswa 29 terdiri dari 17 laki-laki, 12 perempuan. Kemampuan awal matematika rata-rata siswa 72 . KKM matematika kelas IV T.P. 2018/2019. Pembelajaran matematika di kelas IV SD Negeri 003 Bintan Utara berlangsung secara konventional yaitu kegiatan yang masih didominasi oleh guru. Kreatifitas, keaktifan siswa belum tergali dengan maksimal.

Pertemuan pertama pembelajaran diawali dengan siswa berbaris di depan kelas, guru berdiri di depan kelas. Siswa memasuki kelas bersalaman dengan guru. Hal ini dilakukan untuk menanamkan karakter sopan santun terhadap orang yang lebih tua, tertib, dan salingmenghargai. Guru memasuki kelas dengan memberi salam. Berdoa bersama dipimpin oleh siswa yang datang paling awal. Guru menyapa siswa bertanya jawab tentang kabar dan kehadiran 
siswa. Guru mengamati keadaan kelas untuk memastikan petugas piket telah bekerja sesuai Standar Opersional Prosedur yang telah disepakati. Guru melakukan apersepsi dengan bertanya jawab tentang materi yang telah dipelajari sebelumnya. Memastikan kesiapan siswa dengan memberikan kesempatan kepada siswa untuk menyampaikan hal-hal yang dianggap penting. Langkah berikutnya, guru menginformasikan mata pelajaran yang hendak dipelajari hari ini. Guru menyampaiakan tujuan pembelajaran. Guru menjelaskan tentang luas dan keliling bangun persegi, kemudian memberikan contoh soal. Siswa menyimak dan mencatat apa yang diterangkan oleh guru. Kemudian guru memberikan soal-soal yang berhubungan dengan luas dan keliling bangun persegi. Guru mengoreksi hasil pekerjaan siswa. Didapat hasil belajar siswa pada pertemuan pertama masih terdapat lebih $85 \%$ nilai siswa dibawah KKM matematika kelas 4 yaitu 72 .

Pertemuan kedua guru memulai pembelajaran dengan berdiri di depan kelas dan menyalami siswa untuk masuk kelas secara tertib. Guru masuk kelas dilanjutkan berdoa bersama yang dipimpin oleh siswa yang datang paling awal. dan dilanjutkan dengan bertanya jawab tentang kehadiran siswa. Guru bertanya jawab tentang materi yangtelah dipelajari sebelumnya. Memberi soal luas dan keliling bangun persegi untuk mengingatkan materi yang telah dipelajari sebelumnya. Kemudian guru menjelaskan materi luas dan keliling bangun persegi panjang. Siswa menyimak dan mencatat hal-hal yang disampaikan oleh guru. Guru memberikan soalsoal yang berkaitan dengan luas dan keliling bangun persegi panjang. Guru memeriksa hasil pekerjaan siswa. Pada pertemuan kedua hasil ratarata nilai pekerjaan siswa masih belum ada peningkatan dibandingkan dengan pertemuan pertama.

Pertemuan ketiga guru memulai pembelajaran dengan berdiri di depan kelas dan siswa bersalaman memasuki kelas secara tertib. Guru menyapa dan bertanya jawab tentang kehadiran siswa dilanjutkan dengan berdoa. Yang dipimpin oleh siswa yang datang paling awal. Apersepsi dilakukan dengan guru menanyakan bagaimana cara mencari luas dan keliling bangun persegi dan persegi panjang. Kegiatan masih didominasi oleh guru. Guru menjelaskan luas dan keliling bangun segi tiga. Siswa menyimak dan mencatat. Guru memberikan contoh soal siswa mengerjakan soal. Setelah selesai siswa mengumpulkan hasil pekerjaannya ke meja guru. Guru mengoreksi hasil pekerjaan siswa. Dan didapat hasil yang masih belum memuaskan.

Pada pertemuan berikutnya guru memberikan ulangan harian materi luas dan keliling bangun persegi, persegi panjang, dan segi tiga hasilnya kurang memuaskan. Setelah dikoreksi dan analisa terdapat lebih dari $80 \%$ siswa masih berada dibawah KKM matematika kelas IV yaitu 72 . Kemudian guru melakukan remedial dengan cara memberikan tambahan penjelasan mengenai materi kemudian memberikan soal yang berkaitan dengan materi luas dan keliling bangun datar. Hasil remedial belum menunjukkan kenaikan yang signifikan.

\section{Rencana Pelaksanaan Pembelajaran} Discovery Learning. Rencana Pelaksanaan Pembelajaran merupakan salah satu perangkat pembelajaran yang wajib dibuat oleh guru setiap hendak mengajar di kelas. Rencana pelaksanaan pembelajaran merupakan acuan guru dalam melakukan tugasnya di dalam kelas. Oleh sebab itu rencana pelaksanaan pembelajaran menjadi syarat wajib bagi guru.

Menurut Permendikbud Nomor 65 Tahun 2013 tentang Standar Proses, Rencana Pelaksanaan Pembelajaran (RPP) merupakan suatu rencana kegiatan pembelajaran tatap muka untuk satu pertemuan ataupun lebih. RPP brekembang dari silabus untuk lebih mengarahkan kegiatan pembelajaran sperta didik untuk mencapai Kompetensi Dasar.

Dan selanjutnya menurut Permandikbud 81A Tahun 2013 lampiran IV tentang Implementasi Kurikulum Pedoman Umum Pembelajaran, yang pertama dalam pembelajaran menurut standar proses merupakan perencanaan pembelajaran yang diwujudkan dengan kegiatan dalam penyusunan suatu Rencana Pelaksanaan Pembelajaran. RPP merupakan sebuah rencana pembelajaran yang dikembangkan dengan rinci dari materi pokok atau tema tertentu mengacu pada silabus.

Meurut Panduan Teknis Penyusunan RPP di Sekolahan Dasar, RPP merupakan sebuah rencana kegiatan pembelajaran tatap muka untuk satu pertemua atau lebih. RPP dikembangkan dengan rinci dari materi pokok ataupun tema tertentu yang mengacu pada silabus untuk mengarahkan kegiatan pembelajaran siswa dalam upaya mencapai Kompetensi Dasar (KD).

Prinsip-pirinsip Pengembangan RPP berikut: 1. RPP adalah arti dari ide kurikulum bedasarkan siklus yang dikembangkan pada tingkat nasional ke dalam rencangan proses pembelajaran untuk direalisasikan dalam pembelajaran. 2.RPP berkembang sesuai dengan yang telah dinyatakan oleh silabus konsidi pada pendidikan baik kemampuan awal persertaa didik, motivasi belajar,potensi, minat, bakat, gaya belajar, serta kemampuan emosi. 3.RPP harus mendorong dan berpartisipaso secara aktif dalam peserta didik. 4.RPP sesuai dengan tujuan Kurikulum 2013 agar dapat menghasilkan peserta didik yang tak 
berhenti belajar dan mandiri.5.RPP harus dapat mengembangkan budaya baca dan menulis terhadap peserta didik. 6.Kegiatan belajar dalam RPP dirancang untuk mengembangkan kegemaran membaca, pemahaman beragam bacaan, serta berekspresi dalam bentuk tulisan. 7.RPP memiliki ranacangan program pemberian umpan balik positif, remedi, penguatan, umpan balik, serta pengayaan. 8.RPP dibuat dengan memperhatikan keterpaduan dan keterkaitan antara KD dan KI, materi pembelajaran, penilaian, sumber belajar, serta kegiatan belajar dalam keutuhan pengalaman belajar. 9.RPP dibuat dengan pertimbangan pernerapan teknologi komunikasi dan informasi dengan terintegarasi, sistematis, serta efektif sesuai dengan kondisi dan situasi.

Menurut Mulyatiningsih, syntak pembelajaran dalam rencana pelaksanaan pembelajaran model pembelajaran Discovery Learning adalah sebagai berikut: (1) Menjelaskan tujuan pembelajaran, (2) Membagi petunjuk praktikum / eksperimen. (3) Peserta didik melaksanakan eksperimen dibawah pengawasan guru; (4) Guru menunjukkan gejala yang diamati, 5) Peserta didik menyimpulkan hasil eksperimen.

Dari syntak tersebut dapat dideskripsikan bahwa pada metode pembelajaran Discovery Learning guru berperan sebagai fasilitator. Guru memberikan petunjuk kepada siswa dalam melakukan pengamatan, menemukan, mempresentasikan hasil diskusi. Kegiatan lebih banyak didominasi oleh siswa.

Adapun langkah-langkah rencana pelaksanaan pembelajaran model Discovery Learning adalah sebagai berikut: kegiatan awal terdiri dari orientasi peserta didik. Guru membuka pembelajaran dengan salam dan berdoa bersama yang dipimpin oleh peserta didik yang datang lebih awal. Guru memeriksa kehadiran peserta didik.QCX motivasi, dan pemberian acuan kegiatan pembelajaran yang akan dilaksanakan. Pada kegiatan inti terdapat beberapa langkah antara lain: a) orientasi peserta didik meliputi kegiatan mengamati, membaca, mendengar, dan menyimak. b) Pada kegiatan mengorganisasikan peserta didik meliputi menanya. Dalam kegiatan ini siswa diberi kesempatan bertanya.c) pada tahap membimbing penyelidikan individu dan kelompok mencakupkegiatan mengumpulkan informasi, membaca sumber lain, diskusi, presentasi dan tukar informasi. d) Pada tahap mengembangkan dan menyajikan hasil karya adalah mengkomunikasikan hasil diskusi.e) pada tahap menganalisa dan mengevaluasi proses pemecahan masalah adalah mengolah informasi.

\section{Skenario pembelajaran Discovery}

Learning. Skenario pembelajaran diawali dengan siswa berbaris didepan kelas guru berdiri di depan kelas. Siswa bersalaman dengan guru memasuki kelas. Guru memasuki kelas dengan memberi salam. Dilanjutkan dengan tanya jawab kehadiran siswa dan berdoa bersama. Memastikan kesiapan siswa dengan menanyakan apakah ada hal-hal yang akan disampaikan siswa. Pada kegiatan apersepsi guru mengaitkan materi/tema/kegiatan pembelajaran yang akan dilakukan dengan pengalaman peserta didik dengan materi/tema/kegiatan sebelumnya. Mengajukan pertanyaan yang ada keterkaitannya dengan pelajaran yang akan dilakukan. Memberikan gambaran tentang manfaat mempelajari pelajaran yang akan dipelajari. Apabila materi/tema/projek ini kerjakan dengan baik dan sungguh-sungguh ini dikuasai dengan baik, maka peserta didik diharapkan dapat menjelaskan tentang: Menghitung keliling dan luas Persegi. Pada tahap motivasi guru memberikan gambaran manfaat materi, Apabila materi/tema/projek ini kerjakan dengan baik dan sungguh-sungguh ini dikuasai dengan baik, maka peserta didik diharapkan dapat menjelaskan tentang: Menghitung keliling dan luas Persegi Menyampaikan tujuan pembelajaran pada pertemuan yang berlangsung. Pada kegiatan pemberian acuan guru memberitahukan materi pelajaran yang akan dibahas pada pertemuan saat itu,. Pembagian kelompok belajar. Menjelaskan mekanisme pelaksanaan pengalaman belajar sesuai dengan langkah-langkah pembelajaran.

Pada kegiatan inti ada beberapa tahapan kegiatan dalam model pembelajaran Discovery learning antara lain : a) Orientasi Peserta Didik. Sehari sebelum kegiatan peserta didik sudah diberi tugas untuk mencari tahu benda apa saja yang berbentuk persegi. Kegiatan ini melibatkan bantuan orang tua di rumah. Peserta didik diharapkan membaca dari berbagai sumber tentang materi yangakan dipelajari. Selanjutnya, di kelas guru meminta peserta didik untuk menyebutkan benda-benda yang telah didaftar dari rumah. Peserta didik menyimak penjelasan tentang cara mencari luas dan keliling bangun persegi. b) Mengorganisasikan peserta didik.Pada tahap kegiatan ini guru mengajukan beberapa pertanyaan kepada peserta diskusi kelompok tentang bagaimana cara mencari luas dan keliling bangun persegi. Guru memberikan soal-soal untuk diselesaikan dalam kelompok yang telah dibentuk. c) Membimbing penyelidikan individe dan kelompok. pada syntak ini guru memberikan kesempatan kepada peserta didik untuk mengamati dan mencatat hal-hal yang penting tentang cara menghitung luas dan keliling bangun persegi. Kemudian ketua kelompok mengambil 1 bangun persegi dengan ukuran yang bervariasi ke meja guru. Ketua kelompok bersama anggotanya menyelesaikan tugas sesuai permintaan pad bangun datar yang diambilnya. Guru berkeliling untuk memantau jika ada kesulitan yang dialami 
oleh kelompok. d) Mengembangkan dan menyajikan hasil karya. Pada syntak mengembangkan dan menyajikan ini didominasi oleh peran peserta didik. Di tahap ini peserta didik mengembangkan hasil pemahaman mereka dan menyajikan hasil karya secara tertulis dan lisan. Setelah semua kelompok menyelesaikan tugasnya, maka masing-masing kelompok mempresentasikan hasil diskusinya ke depan kelas. e) Menganalisa dan mengevaluasi proses pemecahan masalah. Peserta didik mengolah informasi yang dikumpulkan pada kegiatan diskusi kelompok. Pesaerta didik mengerjakan soal-soal yang berkaitandengan materi luas dan keliling bangun datar persegi, persegi panjang, dan segi tiga.

\section{SIMPULAN DAN SARAN}

Simpulan

Peserta didik di SD Negeri 003 Bintan Utara memerlukan model pembelajaran Discovery Learning yang dapat memberikan kesempatan kepada siswa seluas-luasnya dalam memunculkan kreatifitas, dan kolaboratif dan komunikatif seperti dalam kegiatan: penugasan, siswa menemukan dan mengemukakan hasil temuannya di depan teman-temannya. Peserta didik yang memiliki kemampuan lebih tinggi dibandingkan teman yanglain dapat saling bekerja sama menemukan hal-hal yangterkait pembelajaran.

\section{Rencana Pelaksanaan Pembelajaran} Discovery Learning memiliki tahap-tahapan sebagai berikut: a) Guru membuat kelompok pada kegiatan orientasi peserta didik, b) Mengorganisasikan peserta didik, c) Membimbing penyelidikan individu dan kelompok, d) Mengembangkan dan menyajikan hasil karya, e)Menganalisa dan mengevaluasi proses pemecahan masalah. F)Dimungkinkan dapat menciptakan pembelajaran aktif. Hal ini disebabkan pelaksanaan pembelajaran yang dilakukan dalam kelompok sehingga siswa lebih dominan dalam proses pembelajaran. Siswa dapat menjadi lebih termotivasi dalam pembelajaran karena menggunakan sistem kooperatif dan kompetitif.

\section{Saran}

Berdasarkan pembahasan dan kesimpulan di atas, dapat disarankan beberapa hal sebagai berikut: Mengajar menggunakan model pembelajaran Discovery Learning dengan ketepatan pembagian anggota kelompok siswa yang heterogen dari segi kemampuan intelektual, jenis kelamin, maupun kemampuan kerjasamanya. Dengan demikian hasil yang diharapkan dari diterapkannya model pembelajaran tersebut dapat maksimal. Guru hendaknya menguasai materi pembelajaran dan benar-benar memahami model pembelajaran yang diterapkannya, agar dapat mengatasi kendala yang mungkin terjadi di dalam kegiatan pembelajaran.

\section{DAFTAR PUSTAKA}

Bistari. (2015). Mewujudkan Penelitian Tindakan Kelas (Kenaikan Pangkat Bagi Guru). Pontianak: PT. Ekadaya Multi Inovasi

Hudoyo, H. (1998). Belajar Mengajar Matematika. Jakarta: Depdikbud.

Muchlisin Riadi, 2014 https://www.kajianpustaka.com/2014/04/pem belajaran-matematika.html

Nurdiono, httpa://www.nurdiono.com/pengertiam-soalhots-higher-order-thingking-skill.html

Sulipan, https://sulipan.wordpress.com/2011/05/16/me tode-pembelajaran-penemuan-discoverylearning/ 